\title{
Assessing Barriers to Medication Adherence Among Latinos with Diabetes: a Cross-sectional Study
}

\author{
Andrea Banuelos Mota, BA (1), Emilio Ernesto Feliz Sala, BA, Jennifer M. Perdomo, BS, \\ Joel Alejandro Solis, BA, Walter M. Solorzano, BA, Michael Hochman, MD, MPH, and \\ Jo Marie Reilly, MD, MPH
}

Keck School of Medicine of USC, Los Angeles, CA, USA

J Gen Intern Med 35(2):603-5

DOI: $10.1007 / \mathrm{s} 11606-019-05041-3$

(C) Society of General Internal Medicine 2019

\section{INTRODUCTION}

Latino adults have higher diabetes rates $(12.8 \%)$ than nonLatinos $(7.6 \%)$ and are more likely to have suboptimal glycemic control. ${ }^{1}$ Medication adherence can impact morbidity and mortality from diabetes. ${ }^{2}$ Prior research demonstrates that improving medication adherence among patients with chronic diseases is challenging and that Latino populations may be less adherent to medications than non-Latinos. ${ }^{1,3}$ One study found that $37 \%$ of Latinos had high scores on Morisky Medication Adherence Scale versus 50\% of non-Latinos, indicating poorer adherence among Latinos. 4

In this study, we interviewed Latinos with diabetes to identify modifiable barriers to medication adherence that might be amenable to intervention.

\section{METHODS}

This cross-sectional study assessed patients' perspectives about their challenges with medication adherence. Eligible patients were identified from four safety-net clinics in Los Angeles. From June 2017 to March 2018, patients meeting the following criteria were eligible for the study: age $\geq 18$, self-identified as Latino/ Hispanic/Chicano, diagnosed with diabetes for $\geq 6$ months, and taking $\geq 1$ diabetes medication. Investigators administered the survey to 30 patients at each site, for a total of 120 patients.

The questionnaire included demographic and Likert scale questions about medication adherence barriers and proposed interventions (Appendix). Participants completed the questions

Prior Presentations American College of Physicians Southern California Chapters Scientific Meeting 2017, American Medical Association and Network of Ethnic Physician Organizations 2017 Building Healthy Communities Summit, Southern California Public Health Association Annual Conference 2017, Innovations in Medical Education Conference 2018, Latino Medical Student Association (LMSA) West Regional Conference 2018, and the National Hispanic Medical Association Conference 2018.

Received April 1, 2019

Accepted April 12, 2019

Published online June 3, 2019 independently or with help from the investigator. Upon completion of the survey, participants received a $\$ 10$ gift card.

Survey responses were recorded using Redcap software and analyzed using SPSS. The dependent variable for our analyses was controlled diabetes $(\mathrm{HbA} 1 \mathrm{c}<7.5 \%)$ vs. uncontrolled diabetes $(\mathrm{HbA} 1 \mathrm{c} \geq 7.5 \%)$. We chose a threshold $\mathrm{HbA} 1 \mathrm{c}$ $\geq 7.5 \%$ because when this study began, most major diabetes treatment guidelines recommended a $\mathrm{HbAlc}$ target $<7.0 \%$, but due to emergent data suggesting a less aggressive target, we opted for a more lenient threshold. With 120 participants, our study had a power of $76 \%$ to detect a difference in reported adherence rates of 0.24 on the Likert scale between participants with controlled vs. uncontrolled diabetes.

This study was approved by the University of Southern California's Institutional Review Board (HS-17-00414).

\section{RESULTS}

Table 1 provides demographic characteristics of our study population $(n=120)$. Most subjects were female, Spanishspeaking, with an average age of 60 , and with minimal formal education. On average, our patients took 6.5 prescribed medications daily and the majority (62\%) had a HgbAlc $\geq 7.5$.

Table 1 Demographics of Study Participants $(N=120)$

\begin{tabular}{lll}
\hline \hline Variable & & $N$ \\
\hline Sex & Male & $46(38 \%)$ \\
& Female & $74(62 \%)$ \\
HbAlc & $<7.4$ & $46(38 \%)$ \\
& $\geq 7.5$ & $74(62 \%)$ \\
Age & Mean \pm SD (range) & $60 \pm 12(24-88)$ \\
Health insurance & Public & $104(87 \%)$ \\
& Private & $7(6 \%)$ \\
& No insurance & $5(4 \%)$ \\
Education $(N=119)$ & Other/do not know & $4(3 \%)$ \\
& No school-middle school & $87(73 \%)$ \\
Years outside the USA & Some HS-HS & $22(19 \%)$ \\
$(N=104)$ (range) & College and above & $10(8 \%)$ \\
Language $(N=119)$ & Mean \pm SD & $34 \pm 12(10-70)$ \\
& English & \\
Daily medications & Spanish & $6(5 \%)$ \\
(range) & English and Spanish & $102(85 \%)$ \\
& Mean \pm SD & $6.5 \pm 3.1(1-15)$ \\
& &
\end{tabular}


Table 2 Patient Views Regarding Medication Adherence

\begin{tabular}{|c|c|c|}
\hline \multicolumn{3}{|c|}{$\begin{array}{l}\text { A. Barriers to medication adherence for patients with controlled vs. } \\
\text { uncontrolled diabetes }\end{array}$} \\
\hline Surveyed barriers & $N$ & $\begin{array}{l}\text { OR }(95 \% \\
\text { CI) }\end{array}$ \\
\hline $\begin{array}{l}\text { It is difficult for me to keep track of when to } \\
\text { take all my medications }\end{array}$ & 120 & $\begin{array}{l}3.13(1.32 \\
7.41)\end{array}$ \\
\hline $\begin{array}{l}\text { It is difficult for me to understand what each } \\
\text { of my medications is for }\end{array}$ & 120 & $\begin{array}{l}2.74(1.19 \\
6.34)\end{array}$ \\
\hline $\begin{array}{l}\text { I do not take my medications because I fear } \\
\text { the side effects }\end{array}$ & 120 & $\begin{array}{l}0.99(0.30 \\
3.25)\end{array}$ \\
\hline $\begin{array}{l}\text { I feel stressed, anxious or in a low mood } \\
\text { about my illness }\end{array}$ & 120 & $\begin{array}{l}2.19(0.94 \\
5.09)\end{array}$ \\
\hline I feel that I take too many medications & 120 & $\begin{array}{l}2.41(1.14 \\
5.13)\end{array}$ \\
\hline $\begin{array}{l}\text { I understand how uncontrolled diabetes } \\
\text { affects my health long term }\end{array}$ & 120 & $\begin{array}{l}1.17(0.34 \\
3.92)\end{array}$ \\
\hline My prescription is in my preferred language & 119 & $\begin{array}{l}1.36(0.39 \\
4.75)\end{array}$ \\
\hline $\begin{array}{l}\text { I cannot afford to buy my medication and/or } \\
\text { diabetic supplies }\end{array}$ & 119 & $\begin{array}{l}1.61(0.74 \\
3.48)\end{array}$ \\
\hline \multicolumn{3}{|c|}{$\begin{array}{l}\text { B. Patient views regarding interventions to improve medication } \\
\text { adherence }\end{array}$} \\
\hline Surveyed interventions & $N$ & $\begin{array}{l}\text { \% agree } \\
(95 \% \mathrm{CI})\end{array}$ \\
\hline $\begin{array}{l}\text { How helpful would it be to follow your } \\
\text { prescription given a personalized picture } \\
\text { prescription? (see image for example) }\end{array}$ & 120 & $\begin{array}{l}71.7(63.0- \\
79.0)\end{array}$ \\
\hline $\begin{array}{l}\text { How helpful would reducing your number of } \\
\text { medications be? }\end{array}$ & 118 & $\begin{array}{l}70.3(61.6- \\
77.8)\end{array}$ \\
\hline $\begin{array}{l}\text { How helpful would it be if your family } \\
\text { members understood your medication } \\
\text { regimen? }\end{array}$ & 120 & $\begin{array}{l}78.3(70.1- \\
84.8)\end{array}$ \\
\hline $\begin{array}{l}\text { How helpful would it be to have weekly } \\
\text { conversations with a personal health coach to } \\
\text { gain better control of your diabetes? }\end{array}$ & 120 & $\begin{array}{l}72.5(63.9- \\
79.7)\end{array}$ \\
\hline $\begin{array}{l}\text { How helpful would it be to attend weekly } \\
\text { education sessions to learn more about } \\
\text { managing your diabetes through lifestyle } \\
\text { changes? }\end{array}$ & 120 & $\begin{array}{l}75.8(67.5- \\
82.6)\end{array}$ \\
\hline $\begin{array}{l}\text { To what extent do you feel that meeting with } \\
\text { community members/peer support groups } \\
\text { would help you? }\end{array}$ & 120 & $\begin{array}{l}74.2(75.7- \\
81.2)\end{array}$ \\
\hline $\begin{array}{l}\text { How helpful would it be if you were given a } \\
\text { pillbox for your medications? }\end{array}$ & 119 & $\begin{array}{l}82.4(74.5- \\
88.2)\end{array}$ \\
\hline
\end{tabular}

Table 2 summarizes patient views regarding barriers to medication adherence. Of note, patients with out-of-control diabetes had 3.3 greater odds compared with those with diabetes under control of agreeing that "it is difficult to keep track of when to take all medications" (95\% CI 1.32, 7.41). Also, patients with out-of-control diabetes had 2.74 higher odds of agreeing that "it is difficult for me to understand what each of my medication is for" (95\% CI 1.19, 6.34). Furthermore, patients with out-ofcontrol diabetes had 2.41 higher odds of agreeing that "I feel that I take too many medications" (95\% CI 1.14, 5.13).

The majority of respondents from both groups $(\mathrm{HbAlc} \geq 7.5 \%$ and $<7.5 \%$ ) believed that all of the proposed specific interventions could reduce barriers to diabetes medication adherence. These include personalized picture prescriptions, weekly health education classes, and medication pill boxes (see Table 2B).

\section{DISCUSSION}

Our analysis identified several barriers to diabetes medication adherence associated with suboptimal glycemic control. In particular, patients who struggled to keep track of their medications, those uncertain about what their medications are for, and those who believe they take too many medications were substantially more likely to have out-of-control diabetes. Previous studies also indicate that the better a patient understands their medications, the better they will manage their disease. ${ }^{3}$ Also consistent with our results, Polonksy et al. found that both treatment complexity and convenience are key contributors to decreased adherence. ${ }^{3}$

Our findings suggest several potential approaches for improving medication adherence among Latinos with poorly controlled diabetes. The data indicate that interventions aimed at helping patients keep better track of their medications, educating patients about the treatment indications for their medications, and reducing unnecessary medications all might enhance adherence. Future research should assess the value of such interventions among Latinos with diabetes.

In summary, our results demonstrate that Latino patients with diabetes face substantial barriers to medication adherence, which may adversely impact glycemic control. Our data offers insight into future prospective research evaluating interventions for improved medication adherence in the Latino community.

Acknowledgments: We would like to acknowledge the following individuals and organizations for their invaluable contributions: Rachel Lim, Mike Cruz, MD, Family Care Specialists Medical Group, Clinica Romero-Marengo, Universal Community Health Center, and Edward Roybal Comprehensive Health Center.

Corresponding Author: Andrea Banuelos Mota, BA; Keck School of Medicine of USC, 2020 Zonal Avenue IRD 318, Los Angeles, CA 90033, USA (e-mail: banu932@usc.edu).

Funders This study is funded by the Gehr Center for Health Systems Science and Keck Research Fellowship both at the University of Southern California.

\section{Compliance with Ethical Standards:}

This study was approved by the University of Southern California's Institutional Review Board (HS-17-00414).

Conflict of Interest: The authors declare that they do not have a conflict of interest.

\section{REFERENCES}

1. Mayberry LS, Bergner EM., Chakkalakal RJ, Elasy TA, Osborn CY. SelfCare Disparities Among Adults with Type 2 Diabetes in the USA. Curr Diab Rep (2016) 16: 113 DOI https://doi.org/10.1007/s11892-016-0796-5

2. Centers for Disease Control. Diabetes: At a Glance 2016. Available at: https://www.cdc.gov/chronicdisease/resources/publications/aag/diabetes.htm. Accessed 05 August 2017.

3. Polonsky w, Henry R. Poor medication adherence in type II diabetes: recognizing the scope of the problem and its key contributors. Patient Prefer Adherence. 2016; 10: 1299-1307.

4. Lopez JM, Bailey RA, Rupnow MF, et al. Characterization of type 2 diabetes mellitus burden by age and ethnic groups based on a nationwide survey. Clin Ther. 2014;36:494-506. 


\section{APPENDIX}

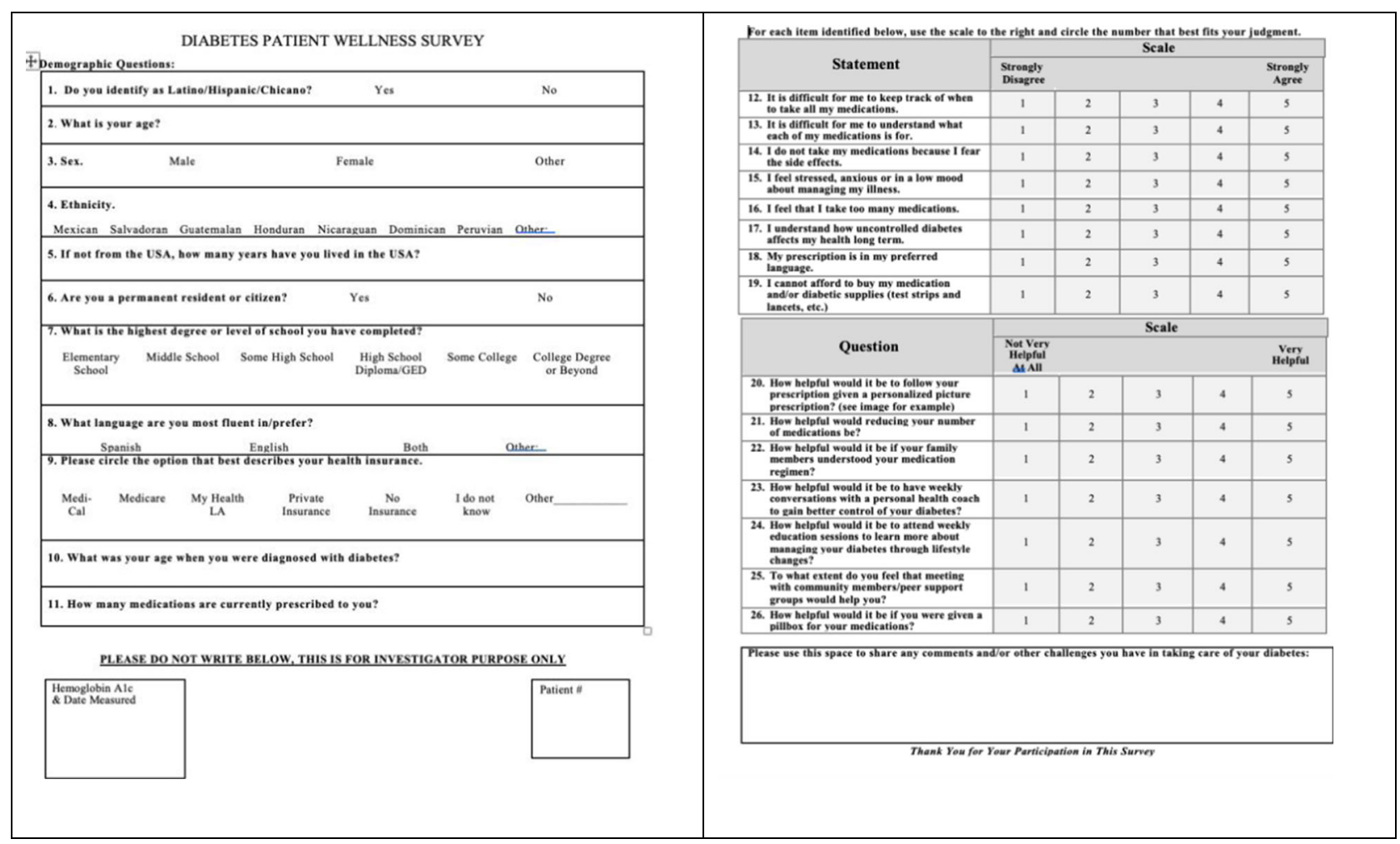

